\title{
CIRI-CIRI, PRINSIP-PRINSIP, JENIS DAN PROSES EVALUASI PENDIDIKAN
}

Yusnita Yusnita ${ }^{1}$, Halawati Halawati ${ }^{2}$, Muhammad Arsyam ${ }^{3}$

\author{
${ }^{1}$ Sekolah Tinggi Agama Islam (STAI) Darud Dakwah Wal-Irsyad (DDI) Kota Makassar, Indonesia \\ Email: yusnitasyarief0@gmail.com \\ ${ }^{2}$ Sekolah Tinggi Agama Islam (STAI) Darud Dakwah Wal-Irsyad (DDI) Kota Makassar, Indonesia \\ Email: halawatihalwa99@gmail.com \\ ${ }^{3}$ Sekolah Tinggi Agama Islam (STAI) Darud Dakwah Wal-Irsyad (DDI) Kota Makassar, Indonesia \\ Email: $\underline{\text { arsyam0505@gmail.com }}$
}

\begin{abstract}
Abstak:
Evaluasi pendidikan dan pengajaran adalah proses kegiatan untuk mendapatkan informasi data mengenai hasil belajar mengajar yang dialami siswa dan mengolah atau menafsirkannya menjadi nilai berupa data kualitatif atau kuantitatif sesuai dengan standar tertentu. Hasilnya diperlukan untuk membuat berbagai putusan dalam bidang pendidikan dan pengajaran. Undang-undang Sistem Pendidikan Nasional nomor 20 tahun 2003 pasal 11 ayat 1 mengamanatkan kepada pemerintah dan pemerintah daerah untuk menjamin terselenggaranya pendidikan yang bermutu (berkualitas) bagi setiap warga negara. Terwujudnya pendidikan yang bermutu membutuhkan upaya yang terus menerus untuk selalu meningkatkan kualitas pendidikan. Upaya peningkatan kualitas pendidikan memerlukan upaya peningkatan kualitas pembelajaran (instructional quality) karena muara dari berbagai program pendidikan adalah pada terlaksananya program pembelajaran yang berkualitas. Oleh karena itu, usaha meningkatkan kualitas pendidikan tidak akan tercapai tanpa adanya peningkatan kualitas pembelajaran.
\end{abstract}

Kata Kunci: Ciri, Prinsip, Jenis, Evaluasi Pendidikan 


\section{A. PENDAhuluan}

Pendidikan Islam merupakan pendidikan yang didasarkan pada nilai-nilai ajaran Islam sebagaimana tercantum dalam al-Qur'an dan al-Hadits serta dalam pemikiran para ulama dan dalam praktik sejarah umat Islam. Dalam prosesnya, pendidikan Islam menjadikan tujuan sebagai sasaran ideal yang hendak dicapai dalam program dan diproses dalam produk kependidikan Islam atau output kependidikan Islam. Adagium ushuliyah menyatakan bahwa : "al-umûr bi maqâshidika", bahwa setiap tindakan dan aktivitas harus berorientasi pada tujuan atau rencana yang telah ditetapkan.

Peningkatan kualitas pembelajaran memerlukan upaya peningkatan kualitas program pembelajaran secara keseluruhan karena hakikat kualitas pembelajaran adalah merupakan kualitas implementasi dari program pembelajaran yang telah dirancang sebelumnya. Upaya peningkatan kualitas program pembelajaran memerlukan informasi hasil evaluasi terhadap kualitas program pembelajaran sebelumnya. Dengan demikian, untuk dapat melakukan pembaharuan program pendidikan, termasuk di dalamnya adalah program pembelajaran kegiatan evaluasi terhadap program yang sedang maupun telah berjalan sebelumnya perlu dilakukan dengan baik. Untuk dapat menyusun program yang lebih baik, hasil evaluasi program sebelumnya merupakan acuan yang tidak dapat ditinggalkan.

Untuk mengetahui ketercapaian suatu tujuan kegiatan yaitu evaluasi. Dengan evaluasi, maka suatu kegiatan dapat diketahui atau ditentukan tarap kemajuannya. Berhasil atau tidaknya pendidikan Islam dalam mencapai tujuannya dapat dilihat setelah dilakukan evaluasi terhadap output yang dihasilkannya. 
Abdul Mujib dkk mengungkapkan, bahwa untuk mengetahui pencapaian tujuan pembelajaran atau kompetensi yang diharapkan oleh peserta didik diperoleh melalui evaluasi. Dengan kata lain penilaian atau evaluasi digunakan sebagai alat untuk menentukan suatu tujuan pendidikan dicapai atau tidak. Atau untuk melihat sejauh mana hasil belajar siswa sudah mencapai tujuannya.

Dalam pendidikan Islam evaluasi merupakan salah satu komponen dari sistem pendidikan Islam yang harus dilakukan secara sistematis dan terencana sebagai alat untuk mengukur keberhasilan atau target yang akan dicapai dalam proses pendidikan Islam dan proses pembelajaran. Dalam makalah ini akan penulis sajikan hal-hal yang menyangkut evaluasi pendidikan Islam, dari mulai pengertian, tujuan, prinsip, fungsi dan perannya.

\section{B. PEMBAHASAN}

\section{Pengertian Evalusi}

Ada tiga istilah yang sering digunakan dalam evaluasi, yaitu tes, pengukuran, dan penilaian. (test, measurement,and assessment). Tes merupakan salah satu cara untuk menaksir besarnya kemampuan seseorang secara tidak langsung, yaitu melalui respons seseorang terhadap stimulus atau pertanyaan (Djemari Mardapi, 2008: 67). Tes merupakan salah satu alat untuk melakukan pengukuran, yaitu alat untuk mengumpulkan informasi karakteristik suatu objek. Objek ini bisa berupa kemampuan peserta did, sikap, minat, maupun motivasi. Respons peserta tes terhadap

sejumlah pertanyaan menggambarkan kemampuan dalam bidang tertentu. Tes merupakan bagian tersempit dari evaluasi.

Pengukuran (measurement) dapat didefinisikan sebagai the process by which information about the attributes or characteristics of thing are determinied and differentiated (Oriondo, 1998: 2). Guilford mendefinisi pengukuran dengan “assigning numbers to, or quantifying, things according to a set of rules" (Griffin \& 
Nix, 1991: 3). Pengukuran dinyatakan sebagai proses penetapan angka terhadap individu atau karakteristiknya menurut aturan tertentu (Ebel \& Frisbie. 1986: 14). Allen \& Yen mendefinisikan pengukuran sebagai penetapan angka dengan cara yang sistematik untuk menyatakan keadaan individu (Djemari Mardapi, 2000: 1). Dengan demikian, esensi dari pengukuran adalah kuantifikasi atau penetapan angka tentang karakteristik atau keadaan individu menurut aturan-aturan tertentu. Keadaan individu ini bisa berupa kemampuan kognitif, afektif dan psikomotor. Pengukuran memiliki konsep yang lebih luas dari pada tes. Kita dapat mengukur karakateristik suatu objek tanpa menggunakan tes, misalnya dengan pengamatan, skala rating atau cara lain untuk memperoleh informasi dalam bentukkuantitatif.

Penilaian (assessment) memiliki makna yang berbeda dengan evaluasi. Popham (1995: 3) mendefinisikan asesmen dalam konteks pendidikan sebagai sebuah usaha secara formal untuk menentukan status siswa berkenaan dengan berbagai kepentingan pendidikan. Boyer \& Ewel mendefinisikan asesmen sebagai proses yang menyediakan informasi tentang individu siswa, tentang kurikulum atau program, tentang institusi atau segala sesuatu yang berkaitan dengan sistem institusi. "processes that provide information about individual students, about curricula or programs, about institutions, or about entire systems of institutions" (Stark \& Thomas, 1994: 46).

Evaluasi memiliki makna yang berbeda dengan penilaian, pengukuran maupun tes. Stufflebeam dan Shinkfield (1985: 159) menyatakan bahwa : Evaluation is the process of delineating, obtaining, and providing descriptive and judgmental information about the worth and merit of some object's goals, design, implementation, and impact in order to guide decision making, serve needs for accountability, and promote understanding of the involved phenomena. Evaluasi merupakan suatu proses menyediakan informasi yang dapat dijadikan sebagai pertimbangan untuk menentukan harga dan jasa (the worth and merit) dari tujuan yang dicapai, desain, implementasi dan dampak untuk membantu membuat keputusan, membantu pertanggung jawaban dan meningkatkan pemahaman terhadap 
fenomena. Menurut rumusan tersebut, inti dari evaluasi adalah penyediaan informasi yang dapat dijadikan sebagai bahan pertimbangan dalam mengambil keputusan.

Berdasarkan pendapat di atas dapat disimpulkan bahwa evaluasi merupakan proses yang sistematis dan berkelanjutan untuk mengumpulkan, mendeskripsikan, mengintepretasikan dan menyajikan informasi untuk dapat digunakan sebagai dasar membuat keputusan dan atau menyusun kebijakan.

\section{Ciri-Ciri Evaluasi Pendidikan}

Adapun ciri-ciri dari evaluasi pendidikan dapat dibagi menjadi beberapa bagian antara lain:

a. Penilaian dilakukan secara tidak langsung

Maksudnya, jika seorang guru ingin mengetahui mana dari siswanya yang cerdas atau kurang cerdas maka dalam evaluasi yang diukur bukanlah kecerdasan atau kekurangan peserta didik, tetapi indikator atau hal-hal yang menandai bahwa seseorang itu bisa disebut pandai dan kurang pandai.

b. Bersifat relative

Salah satu cirri evaluasi adalah bersifat relative karena nilai seorang siswa tidak selalu konstan dari waktu ke waktu, tetapi bisa saja berubah-ubah.

c. Bersifat kuantitatif

Dalam evaluasi pembelajaran biasanya dilakukan pengukuran dengan menggunakan simbol bilangan (angka) sebagai hasil untuk pengukurannya. Hasil pengukuran berupa angka-angka ini kemudian dianalisis dan diinterpretasikan kedalam kata-kata (kualitatif).

d. Sering terjadi kesalahan

Adapun sumber-sumber kesalahan biasanya terletak pada: Alat ukur (soal tes), Pengukur/guru, Yang dinilai (Peserta didik), dan Situasi dimana penilaian berlangsung.

e. Menggunakan satuan unit-unit

Mengenai satuan unit ini yang tepat, seperti sangat memuaskan, memuaskan, cukup memuaskan, kurang memusakan, dan tidak memuaskan. 


\section{Prinsip-Prinsip Evalusi Pendidikan}

Penjelasan mengenai prinsip dalam pelaksanaan evaluasi dapat di bagi dalam kategoti sebagai berikut:

a. Keberlanjutan

b. Keterpaduan

Evaluasi pembelajaran harus memegang prinsip keterpaduan dimana ada kesesuaian antara tujuan instruksional/tujuan pembelajaran, materi pembelajaran, dan metode pembelajaran.

c. Keterlibatan siswa

Keterlibatan siswa dalam kegiatan evaluasi merupakan suatu hal mutlak, karena keterlibatan siswa bukan merupakan suatu alternative. Maka dari itu keterlibatan siswa menjadi salah satu prinsip yang harus dipegang dalam pelaksanaan evaluasi pembelajaran.

d. Koherensi

Prinsip koherensi berarti suatu evaluasi pembelajaran harus berkaitan dengan materi pelajaran yang dipelajari dan harus sesuai dengan ranah kemampuan peserta didik yang akan diukur.

e. Pedagogis

Dalam melakukan kegiatan evaluasi pembelajaran, diperlukan adanya alat penilai dari aspek pedagogis untuk melihat perubahan sikap dan perilaku peserta didik, sehingga pada akhirnya hasil evaluasi dapat dijadikan sebagai motivasi bagi peserta didik untuk menjadi lebih baik.

f. Akuntabilitas

Hasil evaluasi haruslah menjadi bahan pertanggungjawaban bagi pihak yang terkait, seperti sekolah, orang tua peserta didik, dll. 


\section{Jenis Evaluasi Pendidikan}

Pada prinsipnya dalam pelaksanaan evaluasi kita mengenal terkait dengan jenis evaluasi pendidikan yang sesuai dengan kebutuhan bersama, oleh karena itu adapun jenis evaluasi pendidikan sebagai berikut:

a. Jenis Evaluasi Berdasarkan Tujuan antara lain :

1) Evaluasi diagnostic adalah evaluasi yang di tujukan untuk menelaah kelemahan-kelemahan siswa beserta faktor-faktor penyebabnya.

2) Evaluasi selektif adalah evaluasi yang di gunakan untuk memilih siwa yang paling tepat sesuai dengan kriteria program kegiatan tertentu.

3) Evaluasi penempatan adalah evaluasi yang digunakan untuk menempatkan siswa dalam program pendidikan tertentu yang sesuai dengan karakteristik siswa.

4) Evaluasi formatif adalah evaluasi yang dilaksanakan untuk memperbaiki dan meningkatan proses belajar dan mengajar.

5) Evaluasi sumatif adalah evaluasi yang dilakukan untuk menentukan hasil dankemajuan bekajra siswa.

b. Jenis Evaluasi Berdasarkan Sasaran antara lain:

1) Evaluasi konteks adalah yang ditujukan untuk mengukur konteks program baik mengenai rasional tujuan, latar belakang program, maupun kebutuhankebutuhan yang muncul dalam perencanaan

2) Evaluasi input adalah evaluasi yang diarahkan untuk mengetahui input baik sumber daya maupun strategi yang digunakan untuk mencapai tujuan.

3) Evaluasi proses yang di tujukan untuk melihat proses pelaksanaan, baik mengenaikalancaran proses, kesesuaian dengan rencana, faktor pendukung dan faktor hambatan yang muncul dalam proses pelaksanaan, dan sejenisnya.

4) Evaluasi hasil atau produkadalah yang diarahkan untuk melihat hasil program yang dicapai sebagai dasar untuk menentukan keputusan akhir, diperbaiki, dimodifikasi, ditingkatkan atau dihentikan.

5) Evaluasi outcom atau lulusan adalah evaluasi yang diarahkan untuk melihat hasil belajar siswa lebih lanjut, yakni evaluasi lulusan setelah terjun ke masyarakat. 


\section{KESIMPULAN}

Dalam beberapa kajian mendasar dari penjelasan di atas maka selaku penulis artikel ini dapat memberikan kesimpulan sebagai berikut:

1. Peningkatan kualitas pembelajaran membutuhkan adanya peningkatan kualitas program pembelajaran secara berkelanjutan dan berkesinambungan. Untuk meningkatkan kualitas program pembelajaran membutuhkan informasi tentang implementasi program pembelajaran sebelumnya. Hal ini dapat diperoleh dengan dilakukannya evaluasi terhadap program pembelajaran secara periodik.

2. Untuk lebih mengoptimalkan peran guru dalam evaluasi program pembelajaran, maka sebaiknya evaluator dalam evaluasi program pembelajaran merupakan kombinasi antara evaluator dari dalam dan evaluator dari luar dimana evaluator tersebut mempunyai integritas memehami materi, menguasai teknik evaluasi, obbjektif dan cermat, jujur dan dapat dipercaya.

\section{DAFTAR PUSTAKA}

Ramadani, W., Dahri, M., \& Arsyam, M. (2021, January 17). ADMINITRASI KEMITRAAN SEKOLAH DENGAN MASYAKARAT. https://doi.org/10.31219/osf.io/fpm9u

Djemari Mardapi. (2008). Teknik penyusunan instrumen tes dan non tes. Yogyakarta: Mitra Cendekia

Arsi, A., I., \& Arsyam, M. (2021, January 16). Artikel Administrasi Tata Kelola Dalam Pendidikan. https://doi.org/10.31219/osf.io/wsd9r

Nana Sudjana, Ibrahim, 2007,Penelitian dan Penilaian Pendidikan, Sinar Baru Algesindo,

Janna, N. M., A., kurnia, A. d., \& Arsyam, M. (2021, January 14). Administrasi Keuangan Dalam Pendidikan. https://doi.org/10.31219/osf.io/hmvcf

Neta, Y. (2014). Model Tata Kelola Administrasi Pemerintahan Yang Baik di Daerah Otonom Baru. FIAT JUSTISIA: Jurnal Ilmu Hukum, 6(2).

Arsyam, M. (2021). BAHAN AJAR ADMINISTRASI PENDIDIKAN.

Hardiansyah, H., \& Fahmi, A. (2018, September). Strategi Tata Kelola Administrasi Pada Perguruan Tinggi Berbasis Electronic Records. In Prosiding Seminar Nasional Lembaga Penelitian Dan Pendidikan (LPP) Mandala (pp. 246-250).

Mulyasa, Endang. 2007. Manajemen Berbasis Sekolah. Bandung: PT Remaja Rosdakarya.

Arsyam, M. (2020). Manajemen pendidikan islam. 
Zakirah, Z., Jumliadi, J., Arsyam, M., Herianto, H., Rusli, M., \& Alwi, A. M. Implementation of The Islamic Local Regulations in Bulukumba Regency.

Kristiawan, M., \& Asvio, N. (2018). Pengelolaan Administrasi Madrasah Tsanawiyah Negeri Dalam Meningkatkan Kualitas Pendidikan Madrasah. Kelola: Jurnal Manajemen Pendidikan, 5(1), 86-95.

Farida Yusuf Tayibnapis. (2000). Evaluasi Program. Jakarta: Rineka Cipta

Anas Sudijono (1998) Pengantar Evaluasi Pendidikan, Jakarta; P>T. Raja Grafindo Persada

Zakirah, Z., Arsyam, M., HERIANTO, H., \& Umar, K. (2020, December 20). PENDIDIKAN DASAR (KUTTAB) MASA DAULAH ABBASIYAH (132-232 H / 750-847 M). https://doi.org/10.31219/osf.io/7t8bs

Griffin, P. \& Nix, P. (1991). Educational Assessment and Reporting. Sydney: Harcout Brace Javanovich, Publisher.

Makmur, Z., Arsyam, M., \& Alwi, A. M. S. (2020). Strategi Komunikasi Pembelajaran Di Rumah Dalam Lingkungan Keluarga Masa Pandemi. KOMUNIDA: Media Komunikasi dan Dakwah, 10(02), 231-241.

Undang-Undang Nomor 20 Tahun 2003 tentang Sistem Pendidikan Nasional. http//www.evaluasipendidikan.blogspot.com. 